\title{
マイクロチップ電気泳動技術を用いたオンサイト唾液ストレス計測システムの開発
}

\author{
田中 喜 秀*，鳴石奈穂子
}

\section{Development of an On-site Measurement System for Salivary Stress-related Substances Based on Microchip Capillary Electrophoresis Technology}

\author{
Yoshihide TANAKA* and Nahoko NARUISHI \\ Health Technology Research Center, National Institute of Advanced Industrial Science and \\ Technology (AIST) , 1-8-31 Midorigaoka, Ikeda City 563-8577, Japan
}

(Received July 29, 2008)

\begin{abstract}
Psychological stress is of major importance to all age groups in recent years, and may lead to mental disorder and various diseases. An objective and quantitative method for measuring salivary stress-related substances is highly desired because saliva collection is easy, stress free and noninvasive. We have developed a rapid and easy-to-use analytical tool for the measurement of cortisol and secretory immunoglobulin A (sIgA) based on microchip technology, immunoselectivity and electrophoretic separation technique. Performing immunoreaction and capillary electrophoresis (CE) separation on microchips is a promising technique for on-site determination of biogenic substances, and has a few advantages over conventional immunoassay methods: reduced sample size, shortening analysis times, high separation efficiency, reduced cost, and downsizing of analytical system. At this stage of our research, some preliminary prototypes of a highsensitive microchip CE instrument were constructed to determine the stress-related substances in real saliva samples. However, there is not enough detection sensitivity for cortisol analysis. On the other hand, SIgA was successfully analyzed using a laboratory-built microchip CE system and optimal analytical conditions. The sIgA determination is rapid compared with a conventional immunoassay method, and provides an acceptable degree of repeatability and recovery. In the future, microchip technologies will enable total automation and integration of sample preparation. This research has widespread future potential for monitoring multiple stress-related markers within minutes from a trace of saliva, and can contribute to disease prevention and overall good health.
\end{abstract}

Key words_— microfluidic analytical system; stress measurement; saliva; cortisol; secretory immunoglobulin A; immunocapillary electrophoresis

\section{1. はじめに}

現代社会では, 仕事や勉強, 職場・学校・近隣で の人間関係，個人や家庭の諸問題等々，様々なス卜 レス要因（ストレッサー）が曼延しており，多くの 人々が精神的ストレスを抱えていると思われる。過 度なストレスにさらされて心身症, 神経症, うつ病 などに罹り, 残念ながら自殺という最悪のケースに 至る方も少なくない。 また，精神障害による疾病休 業の推定逸失利益（賃金ベース）は国内で約 1 兆円 にのぼり，医療費，周囲のケアに伴う労務費，軽症 の精神障害の存在などを考えると国や企業の損失は

独産業技術総合研究所健康工学研究センター（† 5638577 大阪府池田市緑丘 1-8-31)

*e-mail: yoshihide-tanaka@aist.go.jp

本総説は, 日本薬学会第 128 年会シンポジウム S16 で 発表したものを中心に記述したものである.
さらに膨らむと言われている，急速に少子高龄化社 会を迎え，介護ストレスなども社会問題化しつつあ り，あらゆる世代でのメンタルヘルス対策が急務で ある。

ストレス評価では，問診や質問紙法による心理的 評価法が一般的な方法である。しかしながら，客観 的な方法による精神的ストレスの定量化・指標化は 社会二ーズとして高く, 心拍変動や脳波などの生体 信号変化を捉える生理学的評価法や，血液・尿・唾 液中の生理活性物質を測定する生化学的評価法など の研究開発が進められている。その中で，血液の生 化学的検査は，病気の診断，治療，早期発見や予防 にいまや不可欠な存在ではあるが，穿針採血そのも のがストレス負荷となり，ストレス診断に限れば, 正しく評価できないことが危惧される。 また，スト レス評価は病気の診断・検査のように必ずしも病院 
で行うものではなく，日常生活の場（オンサイト） で簡便・迅速・非侵襲的に測れることも重要な要素 であり，生化学的評価法ではストレスフリーで簡単 に採取できる唾液への注目度が特に高い.

昨今のマイクロ・ナノテクノロジーの進展に伴 い，分析化学分野でも迅速化・高精度化，システム の小型化などで急速な技術革新が進みつつある。半 導体微細加工技術を利用したマイクロチップ（マイ クロ流体チップ，マイクロ化学チップ，ラボチップ (Lab-on-a-chip), Micro Total Analysis Systems ( $\mu \mathrm{TAS})$ とも呼ばれているが，ここでは「マイク ロチップ」と称することにする）がその 1 であり， 最先端の研究から多くの基盤・要素技術が蓄積さ れ，バイオ・医療・健康・環境・食品など様々な分 野への応用展開が図られている。 マイクロチップと は，Fig. 1 のよう五ラスやプラスチックの基板上 に $\mu \mathrm{m}$ オーダーの溶液が流れる微小流路を形成した もので，このマイクロ空間内を利用して，溶液の混 合，反応，精製，分離，検出などの様々なプロセス を効率的かつ自動的に実行する．省サンプルで迅速 分析が可能となり，特にオンサイト臨床診断やバイ オ計測分野で「次世代の分析ツール」として期待が 大きい.われわれは，唾液中のストレス指標物質で あるコルチゾールと分泌型イムノグロブリン A （sIgA）を対象に，このマイクロチップ技術を利用 したオンサイト計測システムの開発に取り組み，チ ップデザイン設計に加え，免疫測定法と電気泳動分 離原理を組み合わせた分析メソッドを構築し，実唾

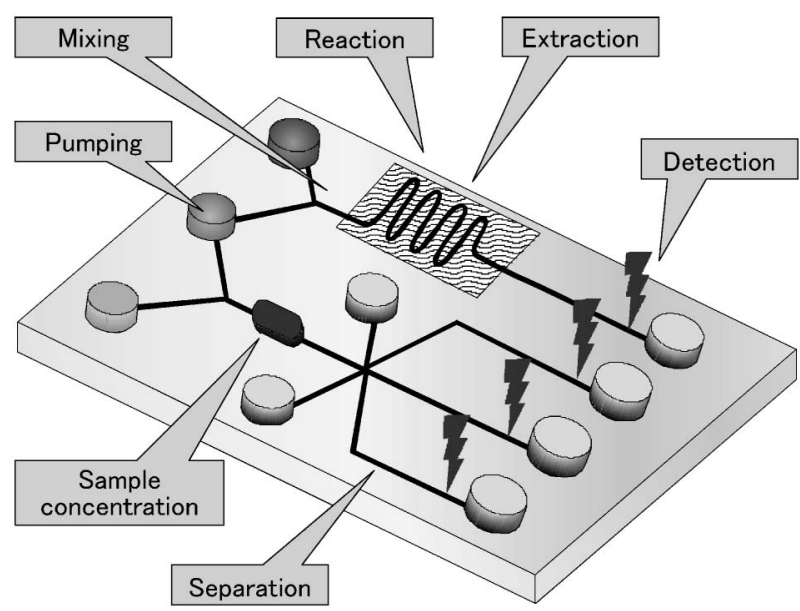

Fig. 1. Schematic Illustration of a Concept of Integrated Microchip
液での測定を可能とした. $\left.{ }^{1,2}\right) \operatorname{sg} \mathrm{A}$ 分析を中心に, 実用化・製品化を目指して積極的に進めており，現 在の開発状況を含めて紹介する.

\section{2. ストレスの生理的メカニズム}

ストレス応答とは，外界からの刺激（ストレッ サー）によって生体の諸バランスが崩れた際に，こ れを回復させる生体の諸反応である。様々なストレ ス応答の基盤になるのは，自律神経系である「視床 下部-交感神経-副腎髄質系（SAM 系）」，内分泌系 である「視床下部-下垂体前葉-副腎皮質系（HPA 系)」, 並びに生体機能調節系である「免疫系」の変 化と考えられている.SAM 系が活性化されると血 液中にカテコールアミンが放出され，血圧上昇，発 汗，血糖上昇，覚醒，戦闘態度などの基礎反応が導 かれ，ストレスに対抗する。一方，HPA 系が活性 化されると血液中に糖質コルチコイドが放出され， 血圧上昇，血糖上昇（糖新生の増加），心収縮力の 上昇，心拍出量の上昇を導くとともに，カテコール アミンの作用に対しても補助的な役割を示す．糖質 コルチコイドの 1 つであるコルチゾールは，ストレ スに敏感に反応して分泌量が増加する生体防御ホル モンであり，ストレスホルモンとも言われている。 もう 1 つの免疫系では，生体の情報伝達制御機構で ある自律神経系と内分泌系の影響を強く受け，慢性 ストレスによって感染抵抗性が低下したり，リンパ 球の反応性やナチュラルキラー細胞の活性が低下す るというストレスに対する免疫機能への影響が報告

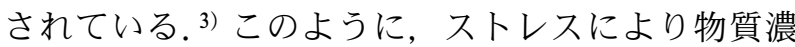
度や活性が変動すると思われる成分を，ストレス指 標物質と言うことにする.

\section{3. 唾液の分泌と神経支配}

唾液は，主に耳下腺，顎下腺，舌下腺の 3 大唾液 腺から分泌され，これに多数の小唾液腺からの分泌 物などが加わり， 口腔内で混合されて全唾液とな る。唾液腺では体液をもとに分泌液（原唾液）が生 成され，血液中の電解質に加え，例えばストレス指 標物質であるコルチゾールも能動輸送により移行す る. ${ }^{3)}$ 血液中ではコルチゾールの大部分はタンパク 質に結合して存在するが，唾液中のコルチゾールは ほとんどが遊離型であり，その濃度は血液中の遊離 型コルチゾール濃度との相関関係が認められてい る. ${ }^{4,5)}$ 一方で，アミラーゼやムチンなどのタンパク 質は唾液腺にある腺房細胞の分泌顆粒に含まれ，開 
口分泌によって腺腔内に放出されると言われてい る. 唾液腺の種類によって腺房細胞に含まれるタン パク質が異なり，例えば耳下腺はアミラーゼを多く 含んだ粘性の低い唾液を分泌するのに対し，顎下腺 や舌下腺はムチンを含んだ粘性の高い唾液を分泌す る. $\operatorname{sg} \mathrm{A}$ や成長因子などは, 唾液の輸送路を形成 する導管細胞から分泌される. ${ }^{6}$

唾液腺は自律神経によって二重支配を受けてお り，ストレス応答により唾液の分泌量や構成成分な ぞが影響する，他の臟器と異なり，唾液腺は交感神 経系及び副交感神経系のいずれの活動六進でも分泌 機能が促進され，交感神経系ではアミラーゼやムチ ンなどを主成分とする粘性の高い唾液が分泌され， 副交感神経系では主として水や電解質からなる粘性 の低い唾液が大量に分泌される。

\section{4. 唾液中のストレス指標物質}

4-1. 自律神経系 カテコールアミン（アドレ ナリン，ノルアドレナリン，ドーパミン）は交感神 経系の直接的な指標であり，ストレス評価では古典 的に用いられてきた，ストレス応答により血液中に カテコールアミンが放出されると，唾液中にも能動 輸送されると考えられる。しかしながら，唾液中の カテコールアミン濃度は極めて低いため（数十～数 百 $\mathrm{pM}$ 以下)，検出するには超高感度な測定法が必 要となる.7）また，仮に全唾液からカテコールアミ ンが検出できたとしても，歯周病等による血液混入 による血液由来のカテコールアミンの可能性は否定 できず，加えてカテコールアミンは唾液中ですぐに 分解が始まることもあり，全唾液では正確に定量で きないことが予想される，そこで，カテコールアミ ンに代わるストレス指標物質の探索が進められ，ク ロモグラニン $\mathrm{A}$ が抽出された。 ${ }^{8)}$ 血液中へカテコー ルアミンと共に放出されると言われており，SAM 系の活動を示す指標とすることができる．ただし， この系は運動負荷時にも活性化されるため，血液中 のクロモグラニン $\mathrm{A}$ 濃度では運動負荷の影響を考 慮する必要がある。一方, 唾液中のクロモグラニン A は運動負荷のみで明確な変化を示さず，精神的 ストレスにのみに反応すると言われている。このこ とから，唾液中のクロモグラニン $\mathrm{A}$ は血液中から 移行したものでなく，顎下腺導管部に存在するクロ モグラニン A が，自律神経刺激により唾液中に放 出されていると考えられている.9
自律神経系が関与しているもう 1 つのストレス指 標物質として，唾液アミラーゼ（ $\alpha$-アミラーゼ）が 挙げられる，唾液アミラーゼは，交感神経系の直接 神経作用などにより分泌され，ストレスにより濃度 が増加すると考えられている. ${ }^{10)}$ 唾液中に最も多く 含まれる酵素で，分析し易いこともあり，SAM 系 の神経活動を簡易にリアルタイムに評価する新しい 指標として期待されている。

4-2. 内分泌系 HPA 系の活動六進の指標と しては，コルチゾールが有名であり，カテコールア ミンとともに古典的なストレス指標として広く用い られてきた。コルチゾールは副腎皮質束状層から分 泌される糖質コルチコイドの 1 つで, 血液中の遊離 型コルチゾールは濃度相関的に唾液中へ移行し，特 に精神的・身体的な急性ストレスに対して濃度が数 倍にも上昇する。唾液中のコルチゾールに対する免 疫測定キットも市販されており，コルチゾールを指 標としたストレス研究の報告は非常に多い。 5 ,11) な お，分泌は副腎皮質刺激ホルモン（ACTH）によ りコントロールされているため，早朝に高く午後か ら低いという日内リズムをもつ。本研究を進めるに あたって，われわれも唾液中コルチゾールの日内変 動や学生の卒業論文・修士論文発表会時の精神的又 トレス（プレゼンテーションストレス）に対する影 響について検証した。本被験者実験は，独産業技術 総合研究所倫理委員会の承認を得て, 日内変動実験 は研究所内の職員 4 名, プレゼンテーションストレ ス実験は 8 名の学生に対して実施した。採取した唾 液は，Salimetrics 社製のコルチゾール測定用免疫測 定キット（Expanded Range High Sensitivity Salivary Cortisol Enzyme Immunoassay Kit, Cat. No. SAL 1-3012）で測定した．Fig. 2 にはコルチゾールの日 内変動結果を, Fig. 3 にはプレゼンテーションスト レスによるコルチゾール濃度の上昇例を示す。コン トロール実験として，8名の学生が普段の学生生活 を送った日（発表会当日から 36-56 日前並びに 618 日後）に唾液を測定したが，発表会と同時刻で のコルチゾールの上昇は認められず，プレゼンテー ションの緊張によりコルチゾール濃度が上昇するこ とは明白であった。

4-3. 免疫系 口腔は外界からの異物に対して 最前線にあり，粘膜免疫機構のはじまりの場であ る。唾液はその中心的な役割を担っており， $\operatorname{sgA}$ 


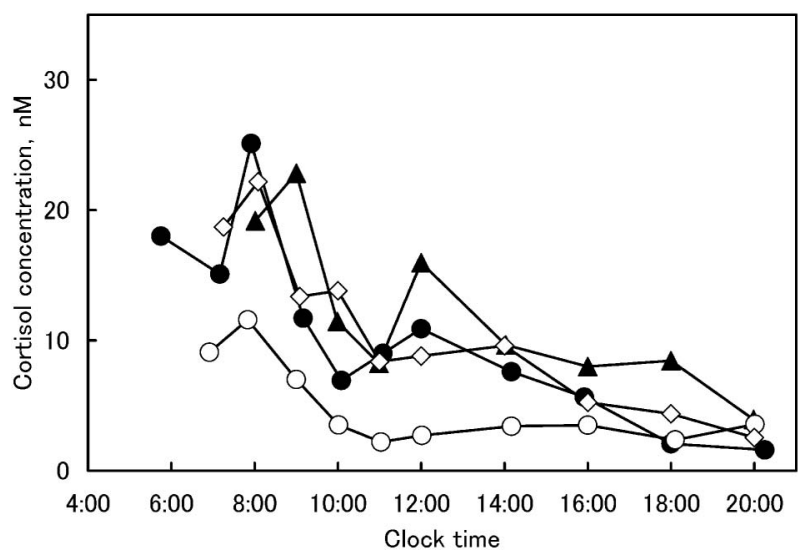

Fig. 2. Circadian Rhythm of Salivary Cortisol in Healthy Four Volunteers

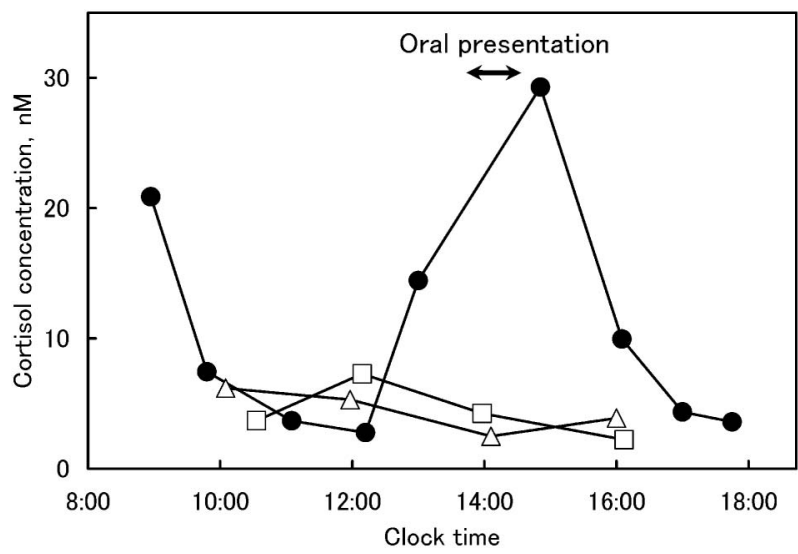

Fig. 3. Effects of Acute Psychological Stress on Salivary Cortisol Levels

Closed circles indicate the data on the academic oral presentation day. Open squares indicate 56 days before the presentation and open triangles 6 days after the presentation.

をはじめ, リゾチーム, ラクトフェリン, ヒスタチ ンなどの免疫, 殺菌・抗菌成分が多数含まれてい

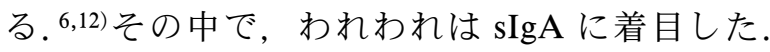

$\operatorname{sIgA}$ は, 口腔, 鼻腔, 消化管なぞの粘膜上の粘液 中に存在し, 粘膜局所の免疫機構において主たる役 割を担っているタンパク質である。また，初乳中に も高濃度の $\operatorname{sgA}$ が含まれ，新生児の感染症防御に 重要な役割を果たしていると言われている。唾液中 には 50-200 $\mu \mathrm{g} / \mathrm{ml}$ 程度の濃度で存在し，血液中に 存在する IgA とは形態が異なるため, 抗原抗体反 応を利用すると唾液中の $\operatorname{sIgA}$ を特異的に検出する ことが可能である.

慢性的なストレスにさらされると，免疫力が低下 して感染症に罹り易くなるというのは多くの人々が
経験していると思われる。しかしがら， $\operatorname{sIgA} の$ ような唾液中の免疫系指標物質と精神的ストレスと の関係を報告した研究は非常にわずかである. ${ }^{13)}$ ス トレス研究の大半が急性ストレスに対するもので, カテコールアミンやコルチゾールがストレス指標と して使われている。慢性ストレスに対するストレス 指標の探索は，これからの重要な研究テーマの1つ であり， $\operatorname{sgA}$ は慢性ストレスの指標として期待し ている，そこで，オンサイトで簡単かつ迅速に測れ るツールを提供できれば，それを多くの方に利用し ていただき，慢性ストレス指標物質としての実証研 究が進むことを期待している.

\section{4-4. ストレス指標物質の分析方法 今回提示} した唾液中のストレス指標物質は，微量で存在する ことが多い。そのため, 分析コストを度外視して高 感度分析装置を利用するか，もしくは特異的かつ高 感度な免疫測定法を利用せざるを得ない，唾液アミ ラーゼに限れば，発色基質を用いた酵素法による測 定キットなどが市販されており, 約 1 時間で多検体 分析が可能である. また，ドライケミストリー方式 を採用して約 1 分で測定できる携带式の分析装置が 開発され, ${ }^{14)}$ ニプロ(秼から「唾液アミラーゼモニ ター」という製品名で販売されている.コルチゾー ル, クロモグラニン $\mathrm{A}, \mathrm{sIgA}$ などの測定は, 特異 的抗体を利用した免疫測定キットが市販され，マイ クロプレートリーダーやピペッターなどの基本的な 装置・設備があれば，実験室レベルで分析可能であ る. しかしながら，この方法では抗原抗体反応の平 衡化に長時間を要することから，総分析時間として 数時間以上を, クロモグラニン $\mathrm{A}$ に至っては 24 時 間以上を必要とする。また, 免疫測定キットは多検 体同時測定（30〜40 検体）には適しているが，日 常生活の場においてストレス評価を目的に，個々人 に対応させたリアルタイム計測には不向きである. ストレス評価では，唾液アミラーゼモニターのよう なオンサイト迅速計測のニーズは高いが，免疫測定 法では, 操作の簡略化や自動化, 精度の向上, 免疫 反応時間（分析時間）の短縮化などに限界がある. そこで，今回紹介するマイクロチップ技術が活かさ れることになる. チップ上に形成された微小の反応 場（微小流路等）を利用することで，サイズの微小 化の 2 乗に比例して拡散時間が短くなることから， 免疫反応などの反応効率が飛躍的に増大し, 分析時 
間の大幅な短縮化が期待できる。その上，試料や抗 体などの使用量は削減でき，分析コストの低価格化 も実現できる，さらに，小さなチップ上に試料前処 理，成分濃縮，分離・検出などのプロセスを集積化 し，分析の自動化も達成可能となる。われわれは， マイクロチップ上で短時間に抗原抗体反応の平衡化 を達成させ，さらに電気泳動原理により高性能な B/ $\mathrm{F}$ 分離（結合型と遊離型の分離）を行うマイクロチ ップ電気泳動技術を利用し， $\operatorname{sg} \mathrm{A}$ やコルチゾール のオンサイト迅速計測を目標に研究開発を進めた.

\section{5. マイクロチップ電気泳動とは}

生体成分や薬物代謝物の分離分析手法として，一 般的には GC, HPLC などが広く普及しているが, キャピラリー電気泳動（CE）は特にイオン性成分 に対して，GCやHPLCよりも高性能な分離手法 として利用されている．CE は，内径 25-100 $\mu \mathrm{m}$ の 溶融石英毛細管（キャピラリー）に電解質溶液（泳
動溶液）を満たして分離の場とし，キャピラリーの 両端に高電圧を印加したときに，溶液中でイオン化 している物質がキャピラリー内を異なる速度で移動 することで分離を達成する。マイクロチップ電気泳 動（マイクロチップ CE）とは，このキャピラリー に代わって，マイクロチップに形成された微小流路 内（例えば幅 $100 \mu \mathrm{m} \times$ 深さ $30 \mu \mathrm{m} ）$ で同様の電気 泳動分離を行う手法で，従来の CE 法の有する特徵 （超微量分析・高分離能）に加え，マイクロ化，高 速分析という利点を兼ね備えており，DNA， RNA，タンパク質などの分析を中心に，最近非常 に注目を集めている分析技術である．Fig. 4 は，マ イクロチップ電気泳動で試料を分析する際の過程を 簡単に図式化したものである.

\section{6. 唾液ストレス計測システムの開発}

6-1. 唾液採取法の検討唾液の採取用具とし て，いくつかの製品が既に市販されているが，Sar-

(a)

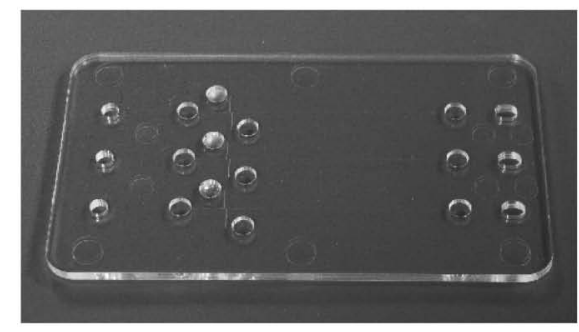

(b)

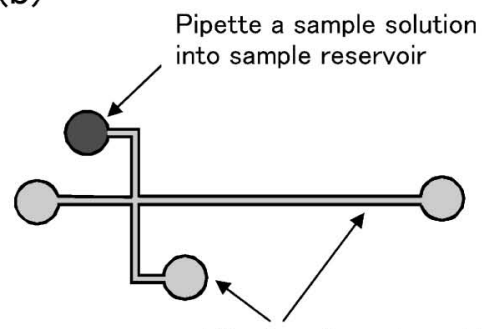

Fill microchannels and buffer reservoirs with an electrolyte

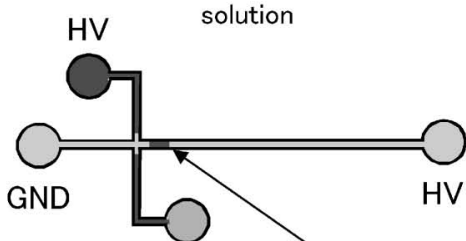

HV Introduce the sample plug into the separation channel by
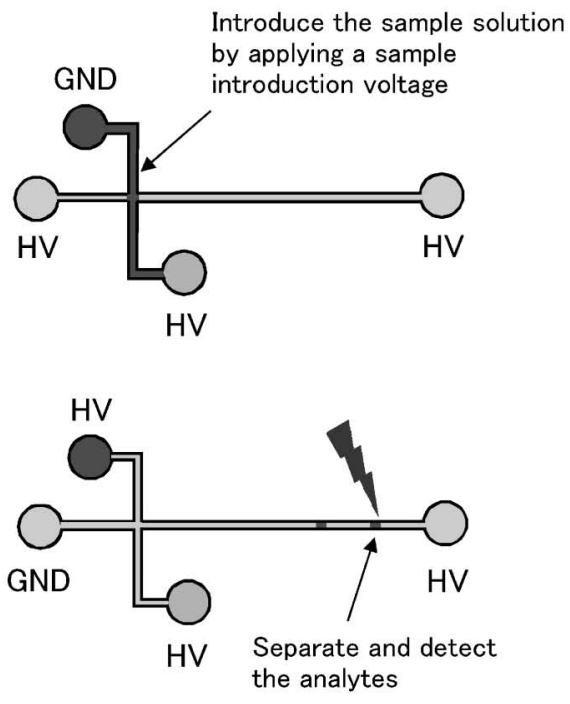

Fig. 4. (a) Photograph of a Developed Microchip for Electrophoretic Separation, and (b) Schematic Illustrations of Experimental Setup, Sample Introduction, Separation and Detection in Microchip CE Analysis HV: applied high voltage, GND: electrical ground. 

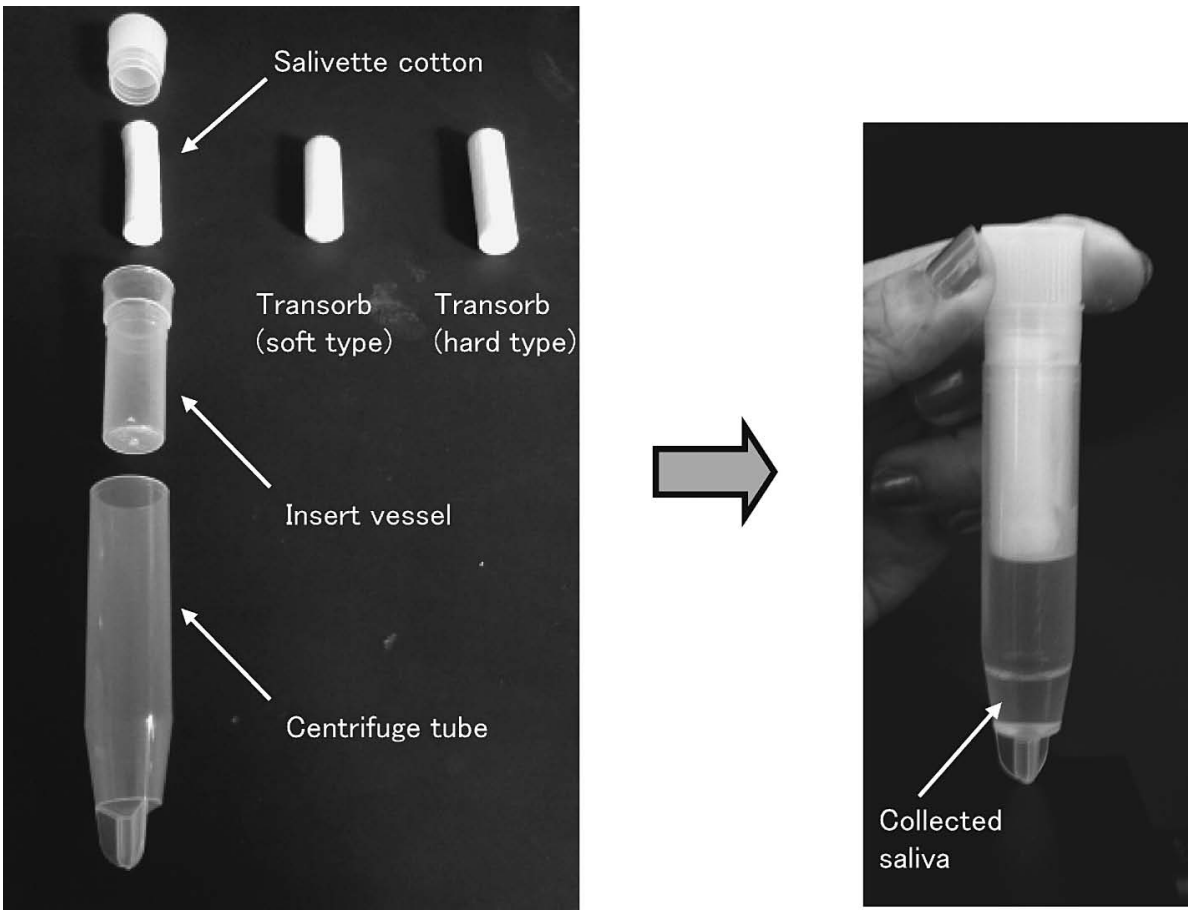

Fig. 5. Photographs of Saliva Sampling Device, Cotton Swabs, and Collected Saliva after Centrifugation

stedt 社のサリベット（Salivette）を利用した研究例 が非常に多い.Fig. 5 に示したコットンを舌下に約 1 分間含み, そのコットンを容器に戻した後に遠心 分離をすることで，唾液を簡単に回収できる。サリ ベットは唾液中のコルチゾール測定には適している が，他のステロイド類では回収率が低下するという

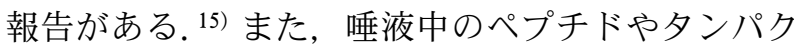
質の測定を目的とした場合，唾液回収用のコットン に吸着して，回収率が低下する可能性も否定できな い. そこで, $\operatorname{sigA}$ 分析に適した唾液採取用具を選 定するために，疎水性成分やタンパク質の吸着が少 ない素材として開発された Filtrona Fibertec 社の Transorb を用いて， sIgA の添加回収実験を行つ た。唾液を容器に直接吐き出してプールし，これに 一定量の $\operatorname{sIgA}$ を添加して調製し，コットンを入れ た唾液採取容器の上から唾液 $1 \mathrm{ml}$ を滴下し, 遠心 分離後の唾液に対して Salimetrics 社製のsIgA 測定 用免疫測定キット（Salivary Secretory IgA Indirect Enzyme Immunoassay Kit, Cat. No. SAL 1-1602) と Pierce 社製のタンパク量測定キット（BCA Protein Assay Reagent Kit, Cat. No. 23227）を用いて, sIgA 濃度と総タンパク量をそれぞれ測定した。そ の結果, Table 1 のようにサリベットでは sIgA の 回収率が低下し，コットンに吸着していることが判
Table 1. Recovery of sIgA Obtained by Direct Collection and by the Use of Different Cotton Swabs

\begin{tabular}{lcrc}
\hline \multirow{2}{*}{ Saliva sampling } & Sample $^{1)}$ & \multicolumn{2}{c}{ Recovery $^{2)}, \%$} \\
\cline { 3 - 4 } & & sIgA & Total protein \\
\hline Direct collection & A & 115.9 & 102.3 \\
& B & 92.0 & 98.8 \\
Cotton swab & & & \\
Salivette & A & 71.0 & 172.9 \\
& B & 72.2 & 119.1 \\
Transorb soft type & A & 102.3 & 97.3 \\
Transorb hard type & B & 96.3 & 93.2 \\
& A & 109.7 & 99.2 \\
& B & 97.9 & 93.6 \\
\hline
\end{tabular}

1) Pooled saliva spiked with SIgA at different concentrations (A: 186.7 $\mu \mathrm{g} / \mathrm{ml}$, B: $933.3 \mu \mathrm{g} / \mathrm{ml}$ ). Endogenous concentrations of sIgA and total proteins were determined in the pooled saliva $(153.66 \mu \mathrm{g} / \mathrm{ml}$ for sIgA and $479.45 \mu \mathrm{g} / \mathrm{ml}$ for total proteins). 2) The percent recovery is calculated by dividing the measured concentration by the expected concentration.

明した。また，総タンパク量の測定では正の誤差を 与える妨害物質の溶出が示唆された。一方, Transorb では概ね $100 \%$ の回収率が得られ，唾液中の sIgA などを定量するには，このような素材のコッ トンを選択すべきことが判明した。

6-2. 分析装置の開発 マイクロチップ電気泳 動は, 微小空間で分離・検出を達成するために, 注 入可能試料量も制限され，濃度感度は低いという弱 
点がある．また，唾液中のストレス関連物質には微 量にしか存在しないものも多く, DNA・RNA 分析 用に開発された市販のマイクロチップ電気泳動装置 では，検出感度が不足していた，そこで，市販のマ イクロチップ電気泳動装置であるコスモアイ SV1100（日立ハイテクノロジーズ社製）の光源を 青色発光ダイオードから青色固体レーザーに変更 し，かつ蛍光標識化物質として選定したフルオレセ インの蛍光特性に適した光学フィルターに交換する ことで，フルオレセインとして 98 倍の高感度化を 達成した。これにより, 固相抽出カートリッジ （OASIS HLB, Waters 社製）を用いて唾液成分を 100 倍に濃縮すれば，Fig. 6 のように実唾液のコル チゾールをかろうじて検出できた．しかしながら， この装置はレーザー光源がむき出しであり，Fig. 6 のフェログラムからも励起光の漏洩が認められ, 安 全性，耐衝撃性などの観点から実用化には程遠いも のであった，そこで，これらの問題点を改良し，同 等の検出感度でベースラインの安定性も確保したプ ロトタイプ装置を試作した。

\section{6-3. マイクロチップ開発と抗原抗体反応の迅速} 化 マイクロチップの大きな利点は，前述したよ うに免疫反応などの反応効率が飛躍的に増大し，分 析時間の大幅な短縮化が期待できることである．わ れわれは，今回クロス型チップの試料リザーバー内 に免疫反応の迅速化機構を組み込んだチップを設 計・開発した。まずは対照実験として，通常の免疫 測定キットで用いられている液量で反応平衡化時間 を確認した。マイクロチューブ内で $\operatorname{sIgA}$ 抗体溶液 $20 \mu \mathrm{l}$, 内標を含む $\operatorname{sIgA}$ 溶液 $40 \mu \mathrm{l}$ 及び人工唾液 40 $\mu \mathrm{l}$ 混合し，反応溶液を一定時間毎に採取して, SIgA と複合体を形成した抗体（免疫複合体）をマ イクロチップ電気泳動で分離・測定し，内部標準 ピークに対するピーク面積比を求めた。 その結果,

Fig. 7 (a) のように反応の平衡化には少なくとも 60 分を要することが判明した. 市販の免疫測定キット では反応平衡化時間を 90 分間に設定しており，今 回の結果は妥当と考えた。なお，Fig. 7 は対照実験 の 60-120 分におけるピーク面積比の平均值を算出 して 100\%の基準值とし，縦軸には反応率に換算し た值をプロットした，次に，開発したチップの試料 リザーバーを利用して，免疫反応の迅速化を実証し た. $4 \mu \mathrm{l}$ の液量で抗原抗体反応を行ったところ,

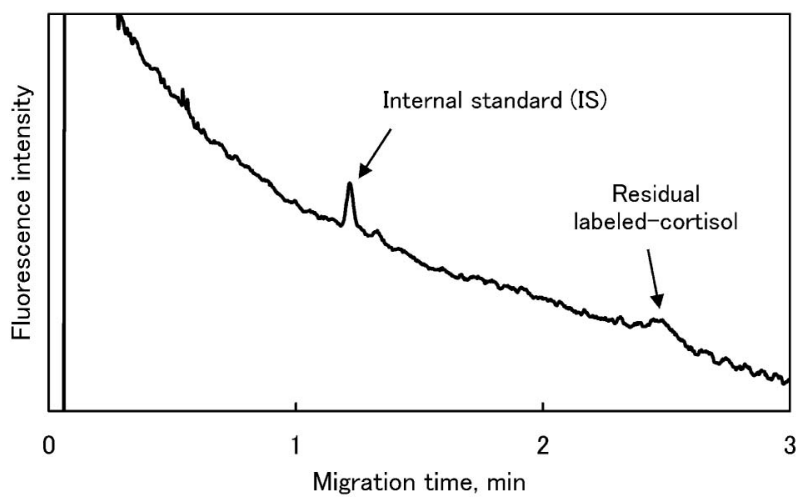

Fig. 6. Analysis of Cortisol in Human Saliva Collected from a Volunteer Using a Microchip-based Immunocapillary Electrophoresis

(a)

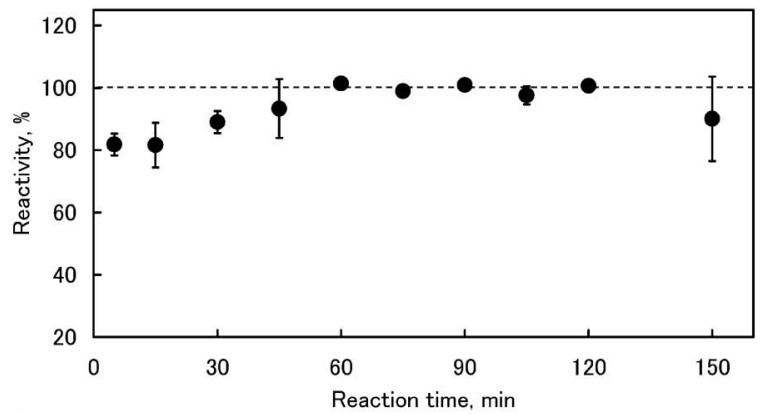

(b)

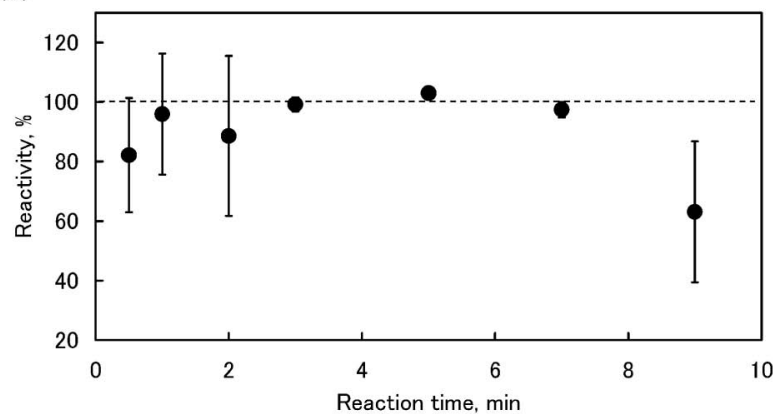

Fig. 7. Equilibrium Curves for the Immunoreaction of SIgA and Antibody (a) Immunoreaction in a $0.6 \mathrm{ml}$ Microcentrifuge Tube, and (b) in a Sample Reservoir of our Developed Microchip

Fig. 7 (b) のように約 3 分で平衡に達し，大幅な迅 速化を達成できた.

6-4. 分析メソッドの開発 免疫測定法では, 免疫複合体と未反応の抗体 (もしくは未反応の抗原) を反応容器から分離除去（B/F 分離）することが 必要である，本法では，試料リザーバー内で反応さ せた溶液の一部を分離チャネルに導入し，そこで高 精度な電気泳動分離技術を利用して，高い $\mathrm{B} / \mathrm{F}$ 分 
離効率を獲得できる，免疫反応として競合法と非競 合法とを選択できるが，一般に低分子化合物が結合 した抗体と未反応の抗体とでは電気泳動移動度の差 がほとんどなく，電気泳動による $\mathrm{B} / \mathrm{F}$ 分離が難し いことから，コルチゾール分析では一定量の抗体に 対して標識抗原と非標識抗原とを競合的に反応させ る競合法を採用した。具体的には，Fig. 8(a) のよ うに唾液試料と一定量の蛍光標識化したコルチゾー ル（標識化コルチゾール）を混合して抗体と反応さ せ，未反応の標識化コルチゾールを分離・定量する ことで唾液中のコルチゾール濃度を算出した。唾液 中のコルチゾール濃度は 1-50 nM 程度であり，装 置での高感度化を図るとともに，分析メソッド開発 でも抗体量や競合抗原量を調節して感度向上に取り 組んだ。その結果，（Fig. 9）のように 1-10 $\mu \mathrm{M}$ （100 倍濃縮前の唾液として 10-100 nM）で検量線 が得られ，Fig. 6 の結果に至った。しかしながら， 現状でも検出感度は不十分であり，実用化には更な る高感度化や試料濃縮機構のオンチップ化による濃 縮倍率の向上など，いくつかの課題が残されている.

一方, SIgA 分析では非競合法を採用して分析メ ソッドを開発した。二次抗体を用いるサンドイッチ 法ではなく，Fig. 8(b) のように一次抗体として蛍 光標識化した抗体（標識化抗体）を用い， $\operatorname{sIgA} と$
の免疫複合体と未反応の抗体とを電気泳動で $\mathrm{B} / \mathrm{F}$ 分離し, $\operatorname{sIg} \mathrm{A}$ 濃度を求めた。唾液中の $\operatorname{sIg} \mathrm{A}$ 濃度は 50-200 $\mu \mathrm{g} / \mathrm{ml}$ と高く, 濃縮等の前処理操作も特に 不要で, 現在のプロトタイプ装置を用いて Fig. 10 のように測定可能であった。なお，実唾液試料を用 いて分析バリデーションを実施したところ, Table 2 のように市販の免疫測定キットと比較しても遜色 ない結果が得られた。

6-6. 免疫測定法との相関前述した日内変動 実験で採取した 16 検体（被験者 3 名）の実唾液に 対して，マイクロチップ電気泳動法と市販の免疫測

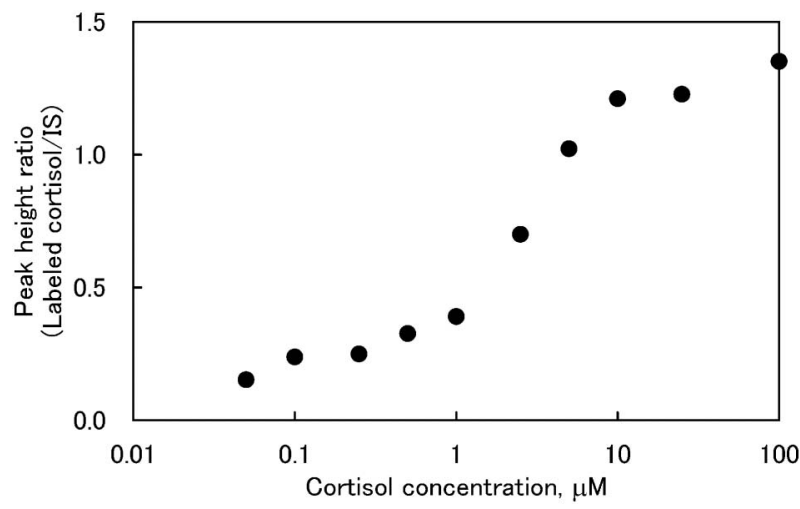

Fig. 9. Calibration Curve Obtained with Different Amounts of Standard (unlabelled) Cortisol

IS: internal standard.

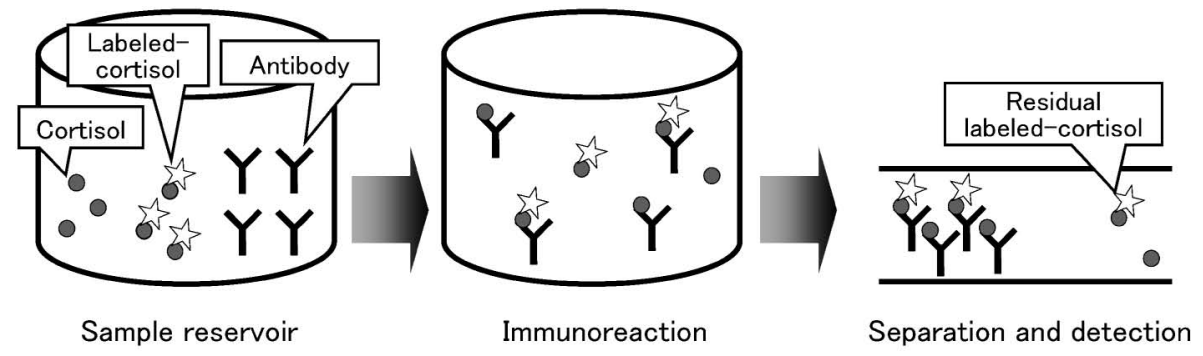

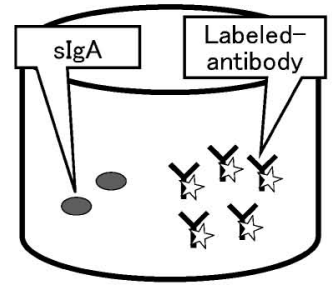

Sample reservoir

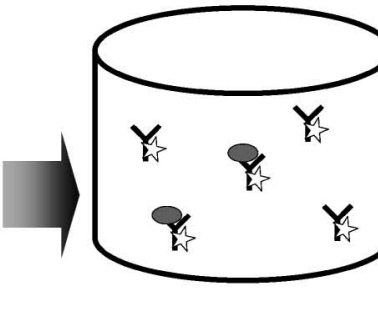

Immunoreaction

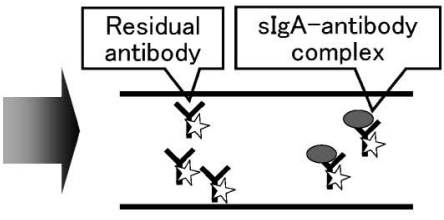

Separation and detection

Fig. 8. Schematic Illustrations showing two kinds of Separation Principle for the Analysis of Salivary Stress-related Compounds using a Microchip-based Immunocapillary Electrophoresis

(a) A competition immunoassay for cortisol analysis and (b) non-competition immunoassay for SIgA analysis. 
(a)

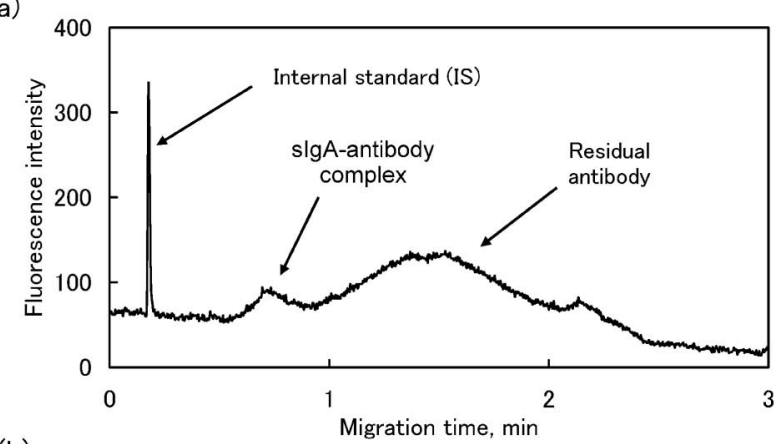

(b)

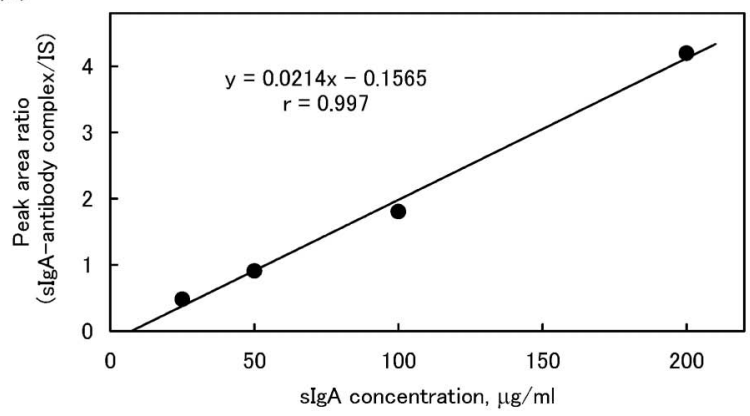

Fig. 10. Analysis of Salivary sIgA using a Microchip-based Immunocapillary Electrophoresis. (a) Representative electropherogram of a saliva sample collected from a volunteer and (b) a linear calibration curve using a commercial sIgA

Table 2. Comparison of Repeatability and Recovery for sIgA Determinations

\begin{tabular}{lcc}
\hline \hline Analytical method & Repeatability, \% & Recovery, \% \\
\hline Microchip CE & $5.7-7.1^{a)}$ & $92.2-107.7^{d)}$ \\
$\begin{array}{l}\text { Immunoassay kit } \\
\text { (Product A) }\end{array}$ & $4.5-7.0^{b)}$ & $100.7-115.9^{e)}$ \\
$\begin{array}{l}\text { Immunoassay kit } \\
\text { (Product B) }\end{array}$ & $5.0^{-9.0^{c)}}$ & $101.0^{-121.4^{f)}}$ \\
\hline
\end{tabular}

Numbers of samples $(\mathrm{N})$ and analytical replicates per sample $(\mathrm{n}): a) \mathrm{N}$ $=3, \mathrm{n}=4 . b) \mathrm{N}=3, \mathrm{n}=10 . c) \mathrm{N}=2, \mathrm{n}=20 . d) \mathrm{N}=6, \mathrm{n}=1 . e) \mathrm{N}=6, \mathrm{n}=$ 2. f) $\mathrm{N}=8, \mathrm{n}=2$. Supplier data from catalog is displayed for immunoassay kits.

定キット（Salivary Secretory IgA Indirect Enzyme Immunoassay Kit，Salimetrics 社製）とで測定を行 い，分析相関性を検証した。その結果，Fig. 11 の ように良好な直線相関は得られたが，両分析法で測 定値は乘離していた。それぞれの分析法で使用した 抗体が異なるために，唾液中の $\operatorname{sIgA}$ に対する親和 性や交差反応性の違いが影響したものと考えてい る.また，チップ法では蛍光標識抗体に結合した唾 液中 $\operatorname{sIgA}$ を直接測定しているのに対し，キット法 では余剰の標識抗体を測定するインダイレクト法を 用いており，測定原理が異なることも要因の可能性

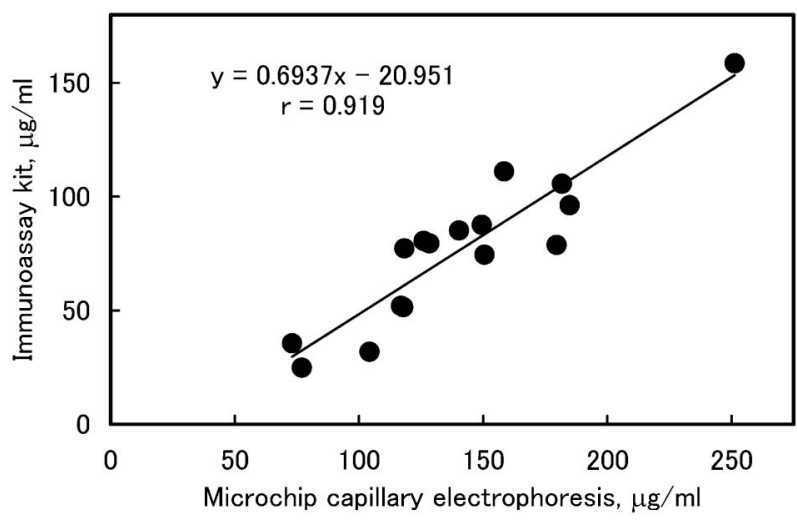

Fig. 11. Comparison between Determinations of sIgA in $\mathrm{Hu}-$ man Saliva Obtained by our Developed Microchip CE Method and by a Conventional Immunoassay Method

として考えている．例えば，複数メーカーの市販 $\operatorname{sIg} \mathrm{A}$ 試薬を用いて，同じ濃度に調製した試料をキ ット法で同時測定したときに，測定值が合わないと いう結果をわれわれは獲得している。タンパク質の ような高分子では，単一構造の標準物質を利用する ことができず， $\operatorname{sIgA}$ 濃度の真值から測定值を検証 することが非常に困難である．今後は，同一の抗体 を使用してマイクロチップ電気泳動法と従来の免疫 測定キット法との分析相関性を検証し，マイクロチ ップ電気泳動法の信頼性を高める必要があると考え ている

\section{8. おわりに}

現代社会ではストレスがもたらす諸問題は深刻で あり，非侵襲で採取できる唾液を用いてストレス評 価が可能になれば，予防医学や健康産業分野へ大き な貢献ができるものと考えている．急速に少子高齢 化が進む中で，医療費削減に加えて，労働生産性を 上げることも必然的に求められるようになり，スト レス管理は今後さらに重要性が増すであろう。あら ゆる世代の人々が，ストレスに対抗して心の健康を 保ち質の高い生活が維持できるように，世の中の仕 組みを築き上げていく必要があると思われる，その なかで，われわれの研究成果が少しでもお役に立て ればと願っている。しかしながら，唾液成分による ストレス評価は現時点で確立されたものではなく， いまだ研究段階にあると考えていただきたい。ま た，ひとつのストレス指標物質で評価するのではな く, 複数の指標物質を組み合わせて利用する必要が あるかもしれない。多種類の指標物質の同時計測に 
際して，「マイクロチップ」という先端技術は大き な可能性を秘めている，進歩を続けるマイクロ・ナ ノテクノロジーを駆使することによって，小さなチ ップ上にたくさんの機能を組み込むことが可能とな り, 唾液 1 滴から短時間での多項目同時計測を目指 したい.

\section{謝辞本研究テーマは, SCIVAX 株式会社} 及びフジプレアム株式会社との共同研究として実施 したものであり，深謝いたします。また，研究遂行 にあたり，脇田慎一チーム長，永井秀典研究員をは じめストレス計測評価研究チームのスタッフ諸氏, Filtrona Fibertec 在日事務所の袴田秀雄氏，日本精 工侏池田憲文氏，日本板硝子侏福澤隆氏，古河電気 工業(侏加藤智也氏など，多くの方にお世話になりま した.この場を借りて感謝いたします。

\section{REFERENCES}

1) Tanaka Y., AIST Today, 6, 24-25 (2006).

2) Tanaka Y., Rinsho Kensa, 52, 441-449 (2008).

3) Irwin M. R., Brain Behav. Immun., 22, 129139 (2008)

4) Lac G., Pathol. Biol., 49, 660-667 (2001).

5) Kirschbaum C, Hellhammer D. H., Psychoneuroendocrinology, 19, 313-333 (1994).
6) Teeuw W., Bosch J. A., Veerman E. C. I., Nieuw Amerongen A. V., Biol. Chem., 385, 1137-1146 (2004).

7) Okumura T., Nakajima Y., Matsuoka M., Takamatsu T., J. Chromatogr. B, 694, 305316 (1997)

8) Nakane H., Asami O., Yamada Y., Harada T., Matsui N., Kanno T., Yanaihara N., Biomed. Res., 19, 401-406 (1998).

9) Kanno T., Asada N., Yanase H., Iwanaga T., Ozaki T., Nishikawa Y., Iguchi K., Mochizuki T., Hoshino M., Yanaihara N., Exp. Physiol., 84, 1073-1083 (1999).

10) Van Stegeren A., Rohleder N., Everaerd W., Wolf O. T., Psychoneuroendocrinology, 31, 137-141 (2006).

11) Fukuda S., Morimoto K., Environ. Health Prev. Med., 6, 9-14 (2001).

12) Nieuw Amerongen A. V., Bolscher J. G. M., Veerman E. C. I., Caries Res., 38, 247-253 (2004).

13) Cohen S., Miller G. E., Rabin B. S., Psychosom. Med., 63, 7-18 (2001).

14) Yamaguchi M., Deguchi M., Wakasugi J., Ono S., Takai N., Higashi, T., Mizuno Y., Biosens. Bioelectron., 21, 1007-1014 (2006) .

15) Gröschl M., Rauh M., Steroids, 71, 1097-1100 (2006). 